when approximately 84 million patients had received the parenteral form.

Typically, those who abuse pentazocine also abuse narcotics and other drugs. ${ }^{1}$ Pentazocine alone does not produce a typical opiate abstinence syndrome, ${ }^{2}$ and withdrawal symptoms are not usually severe and do not require treatment. ${ }^{3}$ In the group reported by Drs King and Betts the symptoms are described as severe, lasting more than two weeks, and resembling those of diamorphine withdrawal. Clearly this runs contrary to the general experience of pentazocine dependence. Subjective testimony alone cannot be regarded as sufficient evidence to establish which drug is being abused, ${ }^{4}$ since it is reported that analysis revealed no trace of pentazocine in six subjects alleging dependence on this drug, while in five there was evidence of morphine or pethidine usage.

Finally, the authors give no indication of the relative frequency of alleged pentazocine abuse. Comparative data are needed to put their experience into correct perspective. If these data could be made available, then the report can be properly evaluated.

C G Nicol Medical Director,

Surbiton, Surre Winthrop Laboratories

Chambers, C D, et al, Health Services and Mental Chambers, $\mathrm{C} \mathrm{D}$, et al, Health Services and
Health Administration Reports, 1971, 86, 627. Health Administration Reports, 1971, 86, 627.
Council on Drugs, fournal of the American Medical Association, 1969, 209, 1518.

${ }^{3}$ Lewis, J R, Fournal of the American Medical Association, 1973, 225, 1530 .

${ }^{4}$ Lancet, 1971, 1, 439.

Roth, C H, and Trout, M E, Hospital Formulary Management, $1970,5,13$

\section{Which drug for hypertension?}

SIR,-Your leading article (8 July, p 75) on the drug therapy of hypertension requires comment. It implies that until the results of the MRC trial of diuretic versus a betablocker are known a thiazide is the drug of choice for virtually all patients with mild to moderate hypertension. However, considerations of cost and long-established usage are not the only criteria for choosing a hypotensive agent.

While accepting that adequate information is not yet available concerning the "cardioprotective" aspects of beta-blocking treatment, many clinicians act ahead of established data and advise the incorporation of beta-adrenergic blockade in all hypotensive regimens when not contraindicated.

If, as the evidence quoted suggests, thiazides reduce the incidence of strokes and betablockers reduce the incidence of myocardial infarction, perhaps a tablet should be made containing a low dose of a long-acting betablocker and a thiazide. Our patients would then gain the benefits of both groups of drugs.

ROGER GABRIEL

Department of Renal Medicine, St Mary's Hospital,
London W2

\section{Parathyroid adenoma}

SIR,-The report by Dr K Y Ahmed and others (8 July, p 92) implies a degree of certainty in the histological diagnosis of parathyroid adenoma which few histopathologists share and suggests a definition of tertiary hyperparathyroidism based on this.
The distinction between parathyroid adenoma and nodular hyperplasia has become increasingly blurred since an "adenoma" producing tertiary hyperparathyroidism was described in $1963 .^{1}$ The difficulty is that an adenoma can be identified only by the demonstration of atrophy of residual parathyroid glands,,$^{23}$ and in many cases with a single prominent parathyroid nodule the remaining parathyroids are either normal or slightly hyperplastic. ${ }^{3}$ Arbitrary classification of these as adenoma is meaningless, and the concept that adenoma and chief cell hyperplasia are different manifestations of the same process ${ }^{2}$ is supported by this evidence. Since the patient described had at least two hyperplastic glands in addition to that containing the "adenoma" the suggestion that the lesion can be sharply categorised as an adenoma seems unwarranted; cases like this of a nodule with a rim of compressed, apparently normal parathyroid occur in hyperplasia. ${ }^{3}$

Furthermore, the terms primary and secondary hyperparathyroidism are defined in a functional sense without regard to the appearances of the parathyroids, and it is logical to define tertiary hyperparathyroidism in the same way. The suggestion that tertiary parathyroidism should be restricted to cases with a histological "adenoma" would merely add confusion because of the uncertainty of the histological diagnosis.

Department of Histopathology,

W K BLENKINSOPP

St Mary's Hospital,

London W2

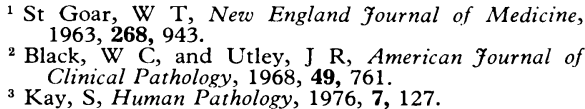

Clinical Pathology, 1968, 49,761.
Kay, S, Human Pathology, 1976, 7, 127.

\section{Propranolol in black hypertensives}

SIR,-Ten years have gone by since Humphreys and Delvin ${ }^{1}$ published their results of a trial of propranolol in the treatment of hypertension in 18 Jamaicans of negro extraction. They included in the discussion a statement based upon their observations in which they said, "We do not think that there is any justification for using propranolol as a hypertensive agent [in Jamaican patients] at the present time...."

I feel that our experience in Jamaica since then makes it timely to refute this point, although I apologise for the fact that I do so a decade later. Since 1968 the drug has been widely used as an antihypertensive agent in the Caribbean and our general opinion is contrary to that of our widely quoted colleagues.

In our unit we have found that, using propranolol alone as an antihypertensive drug, while a response may be achieved at a relatively low dose in some patients, in others only large doses will produce a significant fall in blood pressure. The table shows the mean antihypertensive effect in five patients on propranolol at a dose of $40 \mathrm{mg}$ thrice daily and the mean blood pressure values of four patients on propranolol incrementally increased to a dose of $80 \mathrm{~m}$ j thrice daily. These results suggest that in Jamaican patients with hypertension there are two definable groups based on their dose responsiveness to propranolol. We are investigating the role of renin in this phenomenon. In addition, our studies show that by adding a thiazide diuretic to the therapeutic regimen, a procedure not explored
Hypotensive effect of propranolol in two different dosages (mean blood pressure in $\mathrm{mm} \mathrm{Hg}$ )

\begin{tabular}{|c|c|c|c|}
\hline \multirow{2}{*}{ Blood pressure } & \multicolumn{3}{|c|}{ Week of therapy } \\
\hline & 0 & 8 & 10 \\
\hline \multicolumn{4}{|c|}{$40 \mathrm{mg}$ thrice daily (5 patients) } \\
\hline $\begin{array}{l}\text { Systolic }\left\{\begin{array}{l}\text { Supine } \\
\text { Erect }\end{array}\right. \\
\text { Diastolic }\left\{\begin{array}{l}\text { Supine } \\
\text { Erect }\end{array}\right.\end{array}$ & $\begin{array}{l}162 \pm 6 \\
156 \pm 4 \\
102 \pm 4 \\
107 \pm 2\end{array}$ & $\begin{array}{r}148 \pm 9 \\
134+9 \\
93 \pm 5 \\
96+6\end{array}$ & $\begin{array}{c}139 \pm 11 \\
130 \div 6^{*} \\
85 \div 7 \\
90 \div 7+\end{array}$ \\
\hline \multicolumn{4}{|c|}{$80 \mathrm{mg}$ thrice daily (4 patients) } \\
\hline 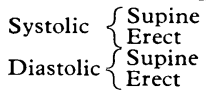 & $\begin{array}{l}163 \pm 10 \\
162 \pm 10 \\
106 \pm 4 \\
107 \pm 3\end{array}$ & $\begin{array}{l}154 \div 6 \\
139+8 \\
100 \div 2 \\
100 \pm 4\end{array}$ & $\begin{array}{c}173: 10 \\
140 \pm 7 \\
99 \pm 1 \\
96 \pm 4\end{array}$ \\
\hline
\end{tabular}

*Significantly different from value at time $0 ; \mathrm{P}<0.005$ †Significantly different from value at time $0 ; \mathrm{P}<0.05$.

by Humphreys and Delvin in 1968, an improved antihypertensive effect can be produced with propranolol.

G A C GReLL

Department of Medicine,

Hypertension Clinic,

University of the West Indies,

Mona, Jamaica

Humphreys, G S, and Delvin, D G, British Medical fournal, 1968, 2, 601 .

\section{Water-soluble lumbar myelography}

SIR,-Dr R G Grainger (3 June, p 1488) rightly stresses the importance of careful radiological technique in minimising the side effects of water-soluble myelography in the investigation of the lumbago-sciatica syndrome. We have found the overall morbidity of water-soluble myelography to be very low and therefore cannot support Dr A K Clarke and his colleagues (29 April, p 1143) in putting forward lumbar venography as an alternative investigation. Lumbar venography is a useful technique in those rare cases in which the appearances on a water-soluble myelogram are thought to be equivocal and surgical treatment is under consideration.

The reports of serious fractures resulting from muscle spasm after the use of meglumine iocarmate (Dimer $\mathrm{X})^{1-3}$ are very worrying. The particular advantage of metrizamide myelography is that muscle spasm does not seem to occur and therefore these rare but nevertheless disastrous fractures should be completely avoidable. With the availability of metrizamide we can see no place whatsoever for the continued use of meglumine iocarmate in the investigation of low back pain and sciatica.

BARRIE PARKER B R REID

Kingston Hospital,
Kingston upon Thames,

Surrey ${ }^{1}$ Hugander, A, et al, Zeitschrift für Rechtsmedizin, ${ }^{2}$ Eastwood, J B, et al, British Medical fournal, 1978 , Morrey, B F, and O'Brien, E T,
foint Surgery, 1977, 59A, 1099.

\section{Housing, health, and illness}

SIR,-Dr J A Muir Gray (8 July, p 100) has performed a valuable service by drawing attention to the role of the medical adviser to a housing authority. We are interested in his observation that at Oxford the community physician could intervene effectively only by using his powers to take cases to committee. 